\title{
Feasibility of the Development of Cruise Terminal in Lavrio Port under Concession Scheme
}

\author{
Evgenios Tassopoulos ${ }^{1}$, Sotirios Theodoropoulos ${ }^{2}$
}

\begin{abstract}
:
Cruise industry is an economic activity experiencing a noticeable growth during the last years worldwide. The efficient exploitation of existing ports and related infrastructures for the development and expansion of this tourism segment of the Greek economy can provide multidimensional benefits. This paper examines the fundamentals qualitative parameters of the port of Lavrio in order to be established as a cruise terminal, decreasing Piraeus port congestion. Efficient cooperation between public sector as owner of infrastructures and private entities providing knowledge and know how in cruise industry can produce high quality services for the clients, ensuring Value for Money and profit maximization for the involved parties. The paper examines the potential for the development of a home port in Lavrio via concession agreement and presents the major parameters that should be evaluated from the public sector for the selection of the optimal bidder. This case study is evaluated in order to examine the feasibility of the investment for the private sector and the potential benefits for the public sector, under specific assumptions under the case study scenario.
\end{abstract}

Key Words:

Cruise Terminal, Concession, Value for Money, Optimal Bidder, Case Study, Feasibility

JEL Classification: $R 40, R 41, R 42, R 48, R 52$

\footnotetext{
${ }^{1}$ Civil Engineer, PhD Candidate, University of Piraeus, Department of Maritime Studies

${ }^{2}$ Professor, University of Piraeus, Department of Maritime Studies
} 


\section{Introduction}

The global cruise market as an economic segment has experienced a noticeable development and steadily growth during the last decades (Di Vaio, 2011) mainly due to the consistent increase of the GDP per capita worldwide. Parameters that affect also the cruise industry can be considered the improvement in quality and cost of the transportations (as a result of the integrated transportation systems) and the characteristics of the cruise as alternative vacation and tourism activity. Cruise activity is considers to be less transportation activity but mainly high quality services related to tourism and pleasure for the passengers (Kendall, 1986), equivalent to high end hotel accommodation services. The pricing of packages over the last years has been adjusted downwards focusing also the middle end consumers instead of only high end clients some years ago (Marti, 2004).

During the period from 2000 to 2010 demand for cruise has been almost doubled from $9.73 \mathrm{mil}$ passengers to $18.80 \mathrm{mil}$ passengers, with the increase only for 2010 to be at the level of $7.50 \%$ (European Cruise Council Report, 2011). The major cruise destination worldwide is Caribbean with the European destinations of Mediterranean and Baltic to follow. Caribbean and Mediterranean Sea attracts more than $60 \%$ of the total passengers. The share of Mediterranean has increased to $21 \%$ on 2009 compared to $15 \%$ on 2004 while the respective share of Caribbean has fallen to $40 \%$ on 2009 instead of $50 \%$ on 2004 (National Bank of Greece, 2012).

The dynamic of the European cruise industry can be justified from the fact that while the tourism sector has experienced a growth of 30\% during the period $2000-2010$, the cruise market has been increased by $175 \%$ servicing $5.5 \mathrm{mil}$ passengers compared to $2.0 \mathrm{mil}$ passengers on 2000. Even at the period of the economic recession during 2008 and 2009, the dynamic of cruise industry had not been slowed down.

Despite the fact that the development and expansion of the cruise industry takes place mainly in western Mediterranean such as Italy (Venice, Genoa, Civitavecchia, Savona) and Spain (Barcelona, Valencia, Majorca), the Greek economy related to cruise tourism and the Greek ports can be developed and established as favorable destinations of companies' itineraries.

The share that Greece holds over the European cruise industry market and the impact over the National economy (in terms of expenditure) is at the lower levels and for 2011 was at $€ 600 \mathrm{mil}$ (representing only the $0.30 \%$ of GDP), meaning that Greece attracts only $4 \%$ of the European market expenditure. Potentials for significant development and expansion of the local cruise industry during the next few years exist. The fact that only few ports in the Eastern Mediterranean can be considered as major home ports reveals that the area is not congested and there is room for Greece to increase its share in the European market (Lekakou, 2009). 
The $€ 600$ mil direct expenditures for Greece during 2011 accounts only the $4 \%$ if the total European market although the country has several famous destinations and ranks at the $3^{\text {rd }}$ place in vessels calls at 4.80mil passengers for 2011 compared to $4.47 \mathrm{mil}$ for 2010 and a share of approximately $18 \%$ from the European total. However, only $6 \%$ of the passengers selected Greece as their embarkation place, from Piraeus port (European Cruise Council, 2011 \& 2012).

There is an obvious inconsistency between the attractiveness of the destinations (port of calls) in Greece and the revenues, mainly due to the low competitiveness of Greek ports as cruise terminals for embarkation and disembarkation. This weakness of the Greek ports has as result low shares in the direct and indirect benefits generated by the cruise market, establishing the country as mainly call destination.

\section{Attractiveness of Lavrio Port for the Development of a Cruise Terminal}

The location of Lavrio port, its basic geographical and technical characteristics and the existing infrastructure, together with the implementation of the necessary regulations by the Greek State regarding the cruise market, can established Lavrio as an alternative home port in Attica, supplementary to the existing terminal of Piraeus. It has been classified, with the Governmental Decree $8315-02 / 02 / 2007$, as a port of International significance for the country. This classification has been made acknowledging the contribution of the subject infrastructure to the transportation network, the strategic location and the potentials of further development ${ }^{2}$. With the development of an alternative home port within Attica region the congestion in Piraeus port can be decreased leading to less delays compared to the existing situation.

Generally there is no a solid correlation between the port efficiency and the ownership structure of the facility (Tongzon, 2005; Di Vaio, 2011). Based on the European experience the cooperation between public sector (as owner of the maritime infrastructure) and schemes of private entities (performing the operation and the management of cruise terminals) has been successfully implemented to some of the major ports such as Barcelona, Venice and Civitavecchia, where the cruise companies are responsible for the provided services.

The knowhow of the private sector and its ability to manage efficient specific risks at a lower cost together with the objective difficulties of the governments to allocate funds for public projects promotes the cooperation between the public and the private sector. This kind of cooperation, which has been applied successfully to maritime industry, can be expanded also to the cruise industry. The objective goal of every party should be to offer high quality services (which coincides with the nature

\footnotetext{
${ }^{2}$ Information regarding the port of Lavrio has been retrieved either on several site visits or through the web site of Port of Lavrio Organization (www.oll.gr)
} 
of the cruise as tourism product) ensuring at the same time Value for Money for the public sector and the efficient returns on private sector investment.

Projects and developments (especially those considered to be large scale) or extensive renovation of existing seems to be unattractive for private sector funds and investors are cautious (Inderst, 2009). These projects usually are less attractive since they require allocation of significant amount of funds, the construction period is long together with the investment characteristics and as a result the return on investment does not meet the required levels (Chlomoudis (2001). Currently the problem is more severe since available funds from the banking sector and financial institutions for infrastructure works are decreasing leading to a more conservative allocation with more strict standards than few years ago $)^{3}$.

Port of Lavrio, apart from the rest advantages that are presented below, has the major part of the necessary maritime infrastructure and transportation network in place and functional which leads to lower level of capital requirements compared to other alternative solutions within Attica region.

There are various studies and research regarding the fundamental characteristics of the ports in order to be suitable and attractive as cruise terminal or port of call, such as those from Peisly (2003), McCalla (1998) and Lekakou, Pallis, Vaggelas (2009). Usually the parameters are taken into consideration as a set of similar variables rather than single factors (i.e. capacity of the port consists of depth, quay walls and docks length etc). Researchers agree that significant parameter for the selection of a port to a cruise company itinerary is the quality of the provided services and the implied cost. Efficient port selection contributes to passengers' satisfaction which is the fundamental factor for companies' success (Henthome, 2000).

\section{Important Factors of Lavrio Port and Potentials for Cruise Terminal Development under PPP Scheme}

Due to serious public budget constraints and the efficient risk management that the private sector can provide has promoted and developed the idea of cruise terminal development and operation under PPP schemes (especially from cruise line companies).

I the case of Lavrio, port infrastructure are in decent level covering the necessary facilities and as a result the additional works for the development of a modern cruise terminal are low budget compared to other alternative scenarios within Attica region. The most important part of the project is related to the building works for the

${ }^{3}$ The fact that capital requirements are higher for infrastructure projects rather that other investment is generally acknowledged. Sawant (2010) and Bitsch (2010) justify it using historical data. 
completion of the terminal which will offer quality services both to passengers / tourists and crew members.

The cooperation between public (i.e. port authority) and the private sector can be a leasehold concession of the infrastructure for a specified time period (i.e. 20 or 25 years) for a specific compensation by the private entity to the state. Concessioner will undertake to perform the necessary building works together with the electromechanical and electronic equipment for the development of a high standard cruise terminal. Revenues for the private entity will be from the operation of the terminal (mooring fees, passengers, services to the cruise vessels) while it will pay to the public sector (port authority) the defined by the concession agreement yearly remuneration. Contractual terms and conditions will be the outcome of a competitive tender procedure between private companies (or $\mathrm{J} / \mathrm{Vs}$ ) that have proven experience on the operation and management of similar facilities together with the financial capacity to perform the project.

Italian ports that have implemented the cooperation with the private sector in the operation and management of cruise terminals managed to improve their performance and efficiency providing better services and obtaining higher profits (Di Vaio (2011).

PPP schemes such as BOT and leasehold concessions have been applied in Greece and as a result of public sector authorities have the necessary experience and knowhow. The relevant legislation has been defined while European Union provides the framework and the directions for such cooperation between public and private sector.

It has been mentioned already that the major factor making a port attractive for cruise companies is the quality of the provided services. Under a PPP scheme the risks associated with project's implementation are distributed to the party which can manage them more efficient (i.e. at a lower cost) (Green Paper on PPP, 2004).

Table 1 presents the factors and criteria that define the suitability of a port to become a cruise terminal. In the case of Lavrio we clarify conceptually which of the involved parties (public or private) can manage more efficient the implied risks to its category, given the fact that the subject risks can be defined at the pre contract stage and included in the contractual documents. The major parameters influencing the homeport selection are those presented in the literature and especially in the study of Lekakou, Pallis, Vaggelas (2009) when assessing the potential of Piraeus as a homeport in Mediterranean $\mathrm{Sea}^{4}$.

${ }^{4}$ Lekakou, Pallis, Vaggelas (2009) used Delphi method (two rounds) on a panel of experts and professionals to the cruise industry, in order to assess the importance of identified factors that the cruise companies take into account when selecting port as a terminal for their 
Table 1: Factors \& criteria that define the suitability of Port of Lavrio to become a cruise terminal

\begin{tabular}{|c|c|c|c|}
\hline $\begin{array}{l}\mathbf{A} / \\
\mathbf{A}\end{array}$ & Factors - Parameters & $\begin{array}{c}\text { Availa } \\
\text { bility } \\
\text { in } \\
\text { Lavrio } \\
\end{array}$ & Risk Allocation \\
\hline 1 & $\begin{array}{c}\text { Availability of an International } \\
\text { airport }\end{array}$ & Yes & $\begin{array}{l}\text { Cannot be included in the concession } \\
\text { agreement }\end{array}$ \\
\hline 2 & $\begin{array}{c}\text { Air connections \& reliable air } \\
\text { transport } \\
\end{array}$ & Yes & $\begin{array}{l}\begin{array}{l}\text { Cannot be included in the concession } \\
\text { agreement }\end{array} \\
\end{array}$ \\
\hline 3 & Political stability & - & $\begin{array}{l}\text { Cannot be included in the concession } \\
\text { agreement }\end{array}$ \\
\hline 4 & Cabotage policy \& incentives & Yes & Public sector (Central Government) \\
\hline 5 & $\begin{array}{c}\text { Maritime infrastructure (depth, } \\
\text { length etc) }\end{array}$ & Yes & Public sector (Port authority) \\
\hline 6 & $\begin{array}{c}\text { Cost of services to cruise vessels } \\
\text { \& passengers }\end{array}$ & - & Private sector \\
\hline 7 & $\begin{array}{l}\text { Facilitation to the passengers } \\
\text { and capacity to service } \\
\text { simultaneously at congestion } \\
\text { time. }\end{array}$ & - & Public sector (Port authority) and Private sector \\
\hline 8 & $\begin{array}{c}\text { Safety for vessels and } \\
\text { passengers - security controls }\end{array}$ & - & Public sector (Port authority) and Private sector \\
\hline 9 & $\begin{array}{l}\text { Adequate land connections of } \\
\text { the port }\end{array}$ & Yes & Public sector (Port authority) \\
\hline 10 & Reliable land transports & Yes & $\begin{array}{l}\text { Cannot be included in the concession } \\
\text { agreement }\end{array}$ \\
\hline 11 & $\begin{array}{l}\text { Attractive tourism activities } \\
\text { (historical or religious places) }\end{array}$ & Yes & $\begin{array}{l}\text { Cannot be included in the concession } \\
\text { agreement }\end{array}$ \\
\hline 12 & Modern cruise terminal & - & Private sector \\
\hline 13 & Hotel infrastructure & Yes & $\begin{array}{l}\text { Cannot be included in the concession } \\
\text { agreement }\end{array}$ \\
\hline 14 & $\begin{array}{l}\text { F\&B and recreation areas } \\
\text { outside port }\end{array}$ & Yes & $\begin{array}{l}\text { Cannot be included in the concession } \\
\text { agreement }\end{array}$ \\
\hline 15 & Adequate parking & Yes & Public sector (Port authority) and Private sector \\
\hline 16 & Appropriate port management & Yes & Public sector (Port authority) and Private sector \\
\hline 17 & Near to cruise itineraries & Yes & $\begin{array}{l}\text { Cannot be included in the concession } \\
\text { agreement }\end{array}$ \\
\hline
\end{tabular}

operation. 
Although the importance of the above parameters to the establishment of a home port has been concluded for the Piraeus case, we do not expect a significant alteration for Lavrio. It appears that Lavrio provides the necessary major infrastructure and other important characteristics to be established as a cruise terminal auxiliary to the main port of the country (Piraeus).

Quality of the services and the relevant cost will be managed by the private sector under the scenario of implementation via a PPP scheme with leasehold concession to be the most appropriate for the subject.

\section{Important Parameters for Optimal Bid Selection}

Due to the competition between the ports (mainly at transportations but also currently at cruise industry) there is a common interest both from the port authority and the private operator of the facilities for the general improvement and management of the port (Wiegmans, 2002). Efficient operation and management by the private operator leads to a more competitive port and higher revenues for the state.

During the implementation of a project under a PPP scheme the public sector defines the services that should be provided and its main objective is the achievement of Value for Money. The benefits can be either pure economic but also non economic benefits for the society, sometimes quantifiable however in many cases difficult to be measured (European PPP Expertise Center, 2011); McCowan, 2003).

At the bidder's selection procedure in BOT and leasehold concession projects and for the calculations of achieving Value for Money the relevant public sector authorities apart from the financial parameters associated with the future cash flow, evaluate also non financial benefits such as financial standing of the participants, track record, quality of the proposal and services.

Similar to every concession agreement, in the case of developing a cruise terminal in Lavrio port the evaluation of the tenders from the public sector is based on the discount of the future cash flows for the public sector generated by the operator of the facility. Revenues for the state usually are the annually payments from the concessioner to the owner of the infrastructure under the terms of the concession agreement. The annual payment is usually adjusted per year based on an escalation following the CPI.

For the evaluation of the optimal tender for the public sector (higher bid) the appropriate selection of the discount rate is a fundamental factor for achieving Value for Money. Discount rate should be calculated at market rates incorporating the risk transfer to the private sector and especially demand risk, construction risk, inflation 
risk, risk of the operation and maintenance in order to ensure the best evaluation criteria (Sadka, 2006); Grimsey, 2005).

Apart from the financial benefits for the public sector that will be evaluated at the bidding procedure other benefits that alternate the various financial offers should be taken into consideration. These parameters are the residual value (ACCA, 2004); Public Private Partnerships, 2007) of the facility upon expiration of the concession period and other non financial benefits such as the employment and the labor related to the specific plans from the investment by each participant to the tender (Chiu, 2004).

\section{Case Study}

\subsection{General assumptions}

Chapter 3 above explores and defines whether Lavrio port features some critical qualitative parameters in order to be considered as possible destination of a home port. Apart from the non financial elements which constitute fundamental and major parameters for success and are being reviewed by the investors and operators, we perform a feasibility analysis for the case study of developing a cruise terminal under specific assumptions and calculation. Estimations and assumptions are based on market figures and experience; however these might change according to the knowledge, expertise and efficiency of the involved parties ${ }^{5}$.

Further deviations might appear due to public sector demands or goals and from the structure of the tender documents. Many of the input were concluded following an interview with the local port authority, where we had the opportunity to understand the strategy of the port itself and the technical possibilities in terms of cruise terminal that the existing facilities provide.

Major parameter is the existing maritime infrastructure and especially the layout that can serve cruise ships at the south - west part of the port which currently also serves cruise ships visiting the port. The future terminal will operate and provide home port as well as port of call facilities.

The demand risk will be managed fully by the private sector which enters into a concession agreement with the public sector (port authority) similar to the scheme applied into Italian port of Savona where the terminal is managed by the cruise company Costa Crociere S.p.A. (Di Vaio, 2011). Demand is the fundamental factor that defines the viability of the investment and the efficient exploitation of the infrastructure.

\footnotetext{
${ }^{5}$ Analysis has been based on the directions provided by EU (2008) "Guide to Cost Benefit Analysis on Investment Projects"
} 
The development of new contemporary buildings that can accommodate and serve the tourists that will choose Lavrio as their home port destination is essential. Together with the buildings (terminal and other supporting areas) investment in necessary equipment is being considered (security, luggage management etc). A time plan of approximately 24 months for the completion of the works is considered to be reasonable based on the assumption that the licensing procedure will be at reasonable levels. The investment cost has been calculated at the range of $€ 3.9 \mathrm{mil}^{6}$. Necessary cost during the operation of the project from the private company or JV has been included in the calculation such as but not limited to labor cost, maintenance, utilities, security, commissions, marketing etc.

Prerequisite for the implementation of the project and the involvement of a private entity with knowledge is the achievement of adequate returns compared to the risks that they are transferred. For the case study we consider reasonable IRRs at the range of $16 \%-20 \%{ }^{7}$. Operation is considered seasonal from May - October and is a pessimistic scenario to avoid market inconsistencies, while the concession period is 25 years. Since the investment will be implemented under a PPP scheme and more specifically under a leasehold concession agreement, the public sector (port authority) will contribute the existing infrastructure with all related maritime facilities and as a result it will benefit remuneration on a yearly basis. This fee can be stable, floating (percentage of the revenues or profits) or combination. Also the annual payment might be adjusted, according to the contractual terms, every year according to the CPI while a lump sum payment is also applicable to such kind of agreements. However analysis of the concession terms, payments to the public sector and applicable models are not subject of this paper.

\subsection{Demand and revenues}

Regardless the legal ownership scheme of each port (public, private, combination), the basic management toll is the pricing policy of the provided facilities (Chlomoudis, 2001). Pricing for the provided services is the factor determines the cost for the user and as a result is major a parameter defining the demand.

Currently there is a specific pricing policy and catalogue for all maritime services that have been approved by the governmental authorities including also the fees for cruise ships ${ }^{8}$ using the port. For the case study and in order to assess whether the

\footnotetext{
${ }^{6}$ The investment cost and the time schedule has been calculated based on the specific case study parameters according to the current market conditions. Of course both can alternate according to the quality and quantity parameters set by the concession agreement or by the concessioner and his design.

${ }^{7}$ This range is considered plausible since it is above the weighted average of the returns realized for investment funds (listed and private) allocated into infrastructure markets for the period 1993 - 2007 (Indesrt 2009).

${ }^{8}$ For details regarding the fees please refer to the Governmental Gazette 518 / 5-4-2011
} 
development of a cruise terminal in Lavrio port, operating auxiliary to Piraeus, is feasible we have applied base and more pessimistic scenarios both for demand and pricing policy, compared to other Mediterranean ports and terminals / ports.

Data collected regarding the demand for the 9 largest ports (in terms of attracting cruise tourists) have been reviewed both for home porting and call porting. Data refers years until 2011 and have been obtained either from reports issued by each port authority or by the European Cruise Council (2012). Special attention has been allocated to the port of Savona in Italy which Lavrio Port management team considers it as having the same characteristics.

We estimate that over 300 thousand tourists each year can use the port as embarkation / disembarkation and around the same number just as port of call when Athens is included in their itinerary. These figures are below the stabilized weighted average from the comparable data and within the 95\% confidence interval. Pricing policy for the base case scenario has been structured based on the one for Piraeus port as it has been defined by the various Government Gazettes ${ }^{9}$.

Private operator will manage apart from any kind of mooring fees, those related to passengers and luggage control and management and every service provided to vessels and crew. Additional income is provided by the efficient exploitation by the land facilities (various commercial areas inside the terminal etc).

\subsection{Monte Carlo Simulation}

Since there are not historical data available both for Lavrio but also for other Greek ports as major cruise terminal in the Mediterranean Sea and cruising market we do not expect that the probability distribution of future outcomes, their expected mean value, their variability of return will follow any of the common distributions.

Monte Carlo simulation can provide a wide range of project's future outcomes and assess the risk - return factors of the investment (mean, variance, kurtosis, skewness of the distribution). We consider the most important parameter for structuring the model to be the demand, which influence revenues significantly, and inflation which affects operation and maintenance cost of the investment plan.

The model has been developed with the possibility of choosing various scenarios of inflation progress while there is a growth trend on the revenues stream. Income and expenses have been treated separately.

\footnotetext{
${ }^{9}$ For details refer to the Government Gazettes 1643/B'/2010, 1601/B'/2011, 3028/B'/2011, 669/B'/2011, 853/B'/2011, 2009/2011, 3033/B'/2011, 3138/B'/2011
} 


$$
N P V=\left(\sum_{n=1}^{25}\left(I_{n}\right)+\sum_{n=1}^{25}\left(C_{n}\right)\right) \times \mathrm{DCF}
$$

Where for the Income (I) and Cost (C):

$\mathrm{I}_{\mathrm{n}}=\mathrm{I}_{\mathrm{n}-1} \mathrm{X}$ rand $(-\mathrm{x} \%,+\mathrm{x} \%$, symmetric triangular distribution)

$\mathrm{C}_{\mathrm{n}}=\mathrm{C}_{\mathrm{n}-1} \mathrm{X}$ rand $(-\mathrm{x} \%,+\mathrm{x} \%$, symmetric triangular distribution)

By applying adequate random paths for every yearly cash flow, it is calculated the Internal Rate of Return (IRR), mean, variance, standard deviation, kurtosis and skewness of the distribution of IRR and the risk factors (Sharp, Treynor Ratio, etc).

For $\boldsymbol{x}=\mathbf{5 \%}$ from the base case scenario both in revenues and expenses it appears that the mean exceeds $21 \%$ making the investment attractive for the private sector while the public sector can benefit from direct payment by the concessioner at the range of $€ 750,000^{10}$ per annum in addition to the indirect benefits to the society. The main results of the Monte Carlo Simulations are as follows:

\begin{tabular}{|c|c|}
\hline \multicolumn{2}{|c|}{ FINAL MONTE CARLO DATA PARAMETERS } \\
\hline MEAN & $21,5346 \%$ \\
\hline KURTOSIS & $-39,2212 \%$ \\
\hline SKEWNESS & $5,1272 \%$ \\
\hline MINIMUM & $19,69 \%$ \\
\hline MAXIMUM & $23,3638 \%$ \\
\hline SAMPLE VARIANCE & $\mathbf{0 , 0 0 4 1 8 \%}$ \\
\hline STANDARD DEVIATION & $\mathbf{0 , 6 4 6 8 \%}$ \\
\hline
\end{tabular}

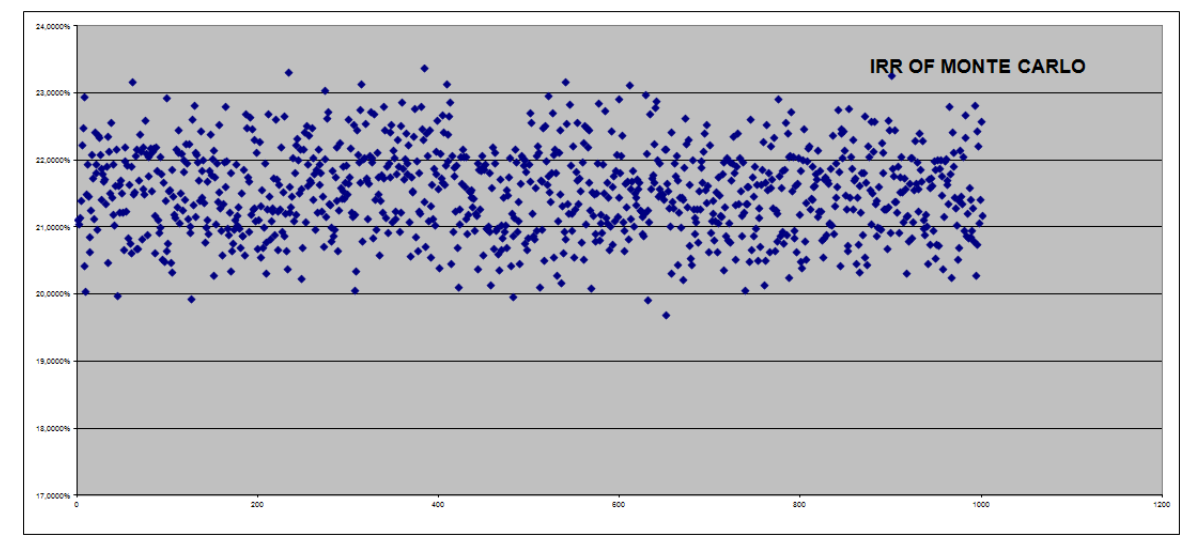

IRR for random paths $(-5 \%+5 \%)$

\footnotetext{
${ }^{10}$ Under this assumption provides lump sum payment is not provided. However this can be modified by the concessioner and an upfront payment might be included by diminishing the yearly fee.
} 
E. Tassopoulos - S. Theodoropoulos

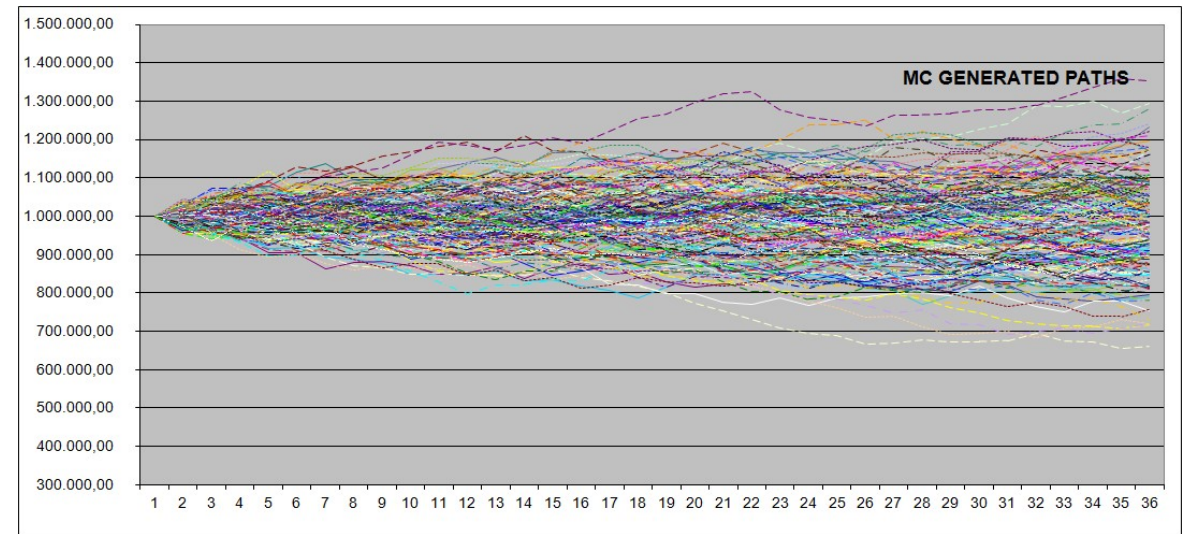

Net profits for each of the random path $(-5 \%+5 \%)$

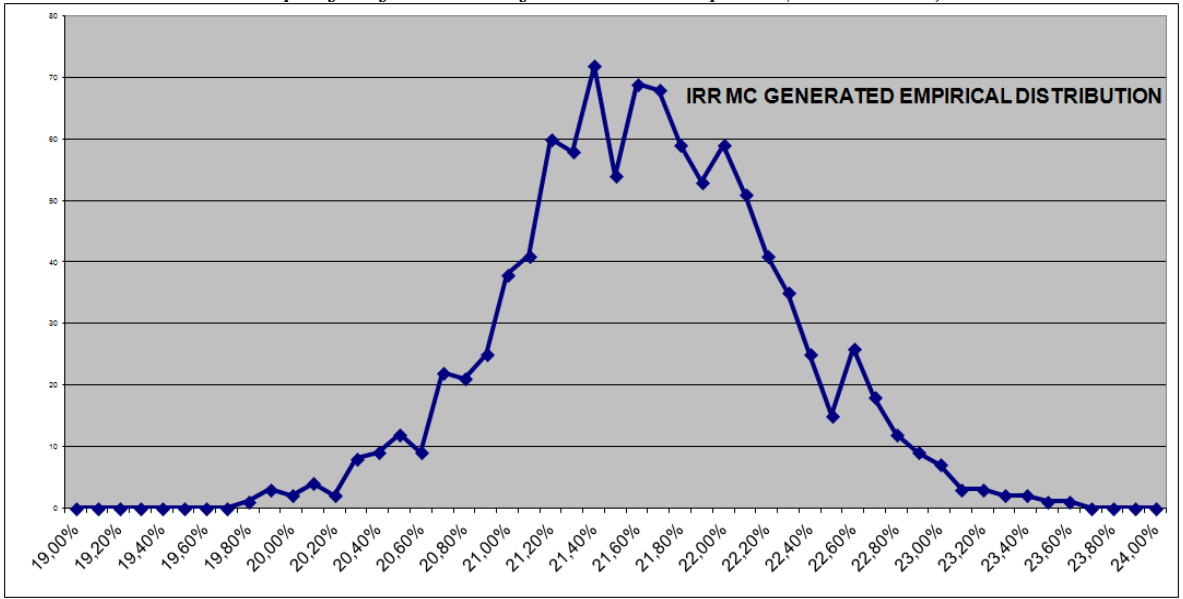

IRR Distribution (-5\% + 5\%)

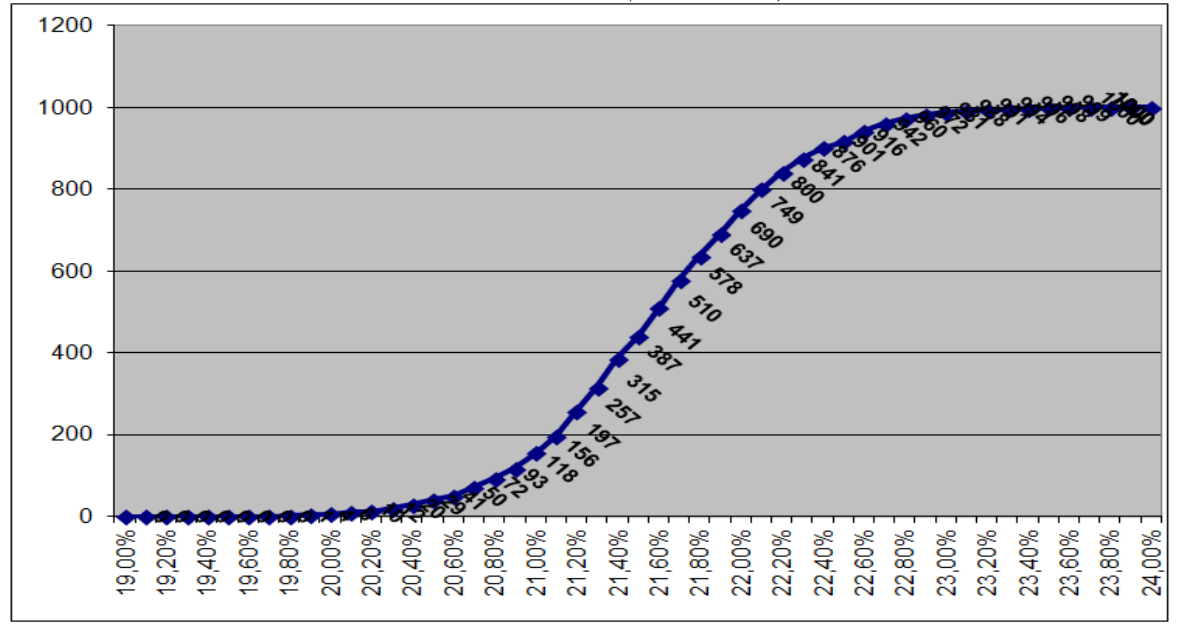

IRR Cumulative Distribution (-5\% + 5\%) 


\section{Conclusion}

The paper explores the fundamentals characteristics of Lavrio port and the possibility to become a home port for cruise itineraries, auxiliary to the main port of Piraeus. It meets most of the important qualitative parameters and critical factors set by the companies to become a cruise terminal. The reasonable level of the investment makes the development of the cruise terminal under a concession agreement attractive for the private sector. Especially the cruise companies have performed successfully similar projects in Mediterranean area and can contribute significant know how and experience.

Experience from the public sector in PPP schemes and the necessary regulation and cabotage police has been implemented which can make the investment more attractive for the private sector participants. Public sector's aim is to maximize the value for money. Competitive tendering procedure can ensure (by following specific requirements) the efficient exploitation of the public infrastructure and the maximization of the benefits for the public.

The viability of the investment has been assessed via Monte Carlo Simulation and under specific parameters for an industry where Greek Ports have a small share in the European Market. Investment can be profitable for a private operator / investor with knowledge on the market. Public sector will face direct (payments) and indirect benefits (social and other) from the implementation of the PPP scheme.

It is reasonable that private entities with knowledge on the cruise market worldwide (i.e. cruise companies) might have better data and modeling regarding both demand and costing that can lead into more accurate results without having to apply advanced statistical modeling to assess viability of the investment.

\section{References}

ACCA (2004), "Evaluating the operation of PFI in roads and hospitals", Research Report No. 84

Bitsch, F., Buchner, A. and Kaserer, C. (2010), "Risk, return and cash flow characteristics of infrastructure fund investments" European Investment Bank Papers, Vol. 15, No 1.

Commission of the European Communities (2004) "Green paper on Public - Private Partnerships and community law on public contracts and concessions", available at http://europa.eu.int

Chiu, C. and Bosher, B. (2004), Risk sharing in various PPP arrangements for the provision of water and wastewater services

Chlomoudis, K. (2001), Organization and Administration of Ports, J \& J Hellas, Piraeus. 
European Commission (2008), Guide to cost - benefit analysis of investment projects; Structural funds, cohesion fund and investment for pre-accession, Directorate General Regional Police, July 2008.

European Cruise Council (2011), The cruise industry: A leader in Europe's economic recovery, available at www.crousecouncil.eu.

European Cruise Council (2012), The cruise industry: Contribution of cruise tourism to the economies of Europe, available at www.crousecouncil.eu.

European PPP Expertise Center (2011), The non financial benefits of PPs; An overview of concepts and methodology, available at http://www.eib.org/epec.

Di Vaio, A., Medda, F. and Trujillo, L. (2011), Public and private management and efficiency index of cruise terminals

Grimsey, D. and Lewis, M. (2005), "Are Public Private Partnerships value for money / Evaluating alternative approaches and comparing academic and practitioner views", Accounting Forum 29, pp. 345 - 378.

Henthome, L. (2000), "An analysis of expenditures by cruise ship passengers in Jamaica", Journal of Travel Research, 38, pp. $246-250$.

Inderst, G. (2009), "Pension fund investment in infrastructure" OECD Working Papers on Insurance and Private Pensions No. 32.

Kendall, L. (1986), The business of shipping, Cornell Maritime Press, Centreville MD.

Lekakou, M., Pallis, A. and Vaggelas, G. (2009), "The potential of Piraeus as a major Mediterranean cruise home port: A selection criteria analysis" $4^{\text {th }}$ International Conference of Tourism, 2009, Rhodes, Greece.

Marti, B. (2004), "Trends in the world and extended length cruising: 1985 - 2002", Marine Policy, 28, pp. $199-211$.

McCalla, R. J. (1998), "An investigation into site and situation: Cruise ship ports", Tijdschrift voor Economische en Sociale Geografie, 89(1), pp. 44-55.

McCowan, A. and Mohamed, S., (2003), Evaluation of BOT project opportunities in developing countries, Griffith University, Australia.

National Bank of Greece (2012), Cruise market: A segment of economy with potential revenues of $€ 2$ bil., August.

Peisly, T. (2003), "Cruising - A global view of the challenge and opportunity" International Association Cities and Ports Days.

Public Private Partnership (2007), Value for Money and the Public Private Partnership procurement process, Ireland, October

Sadka, E. (2006), "Public Private Partnerships; A public economic perspective", International Monetary Fund Working Paper, WP/06/77.

Sawant, R. (2010), "Emerging market infrastructure project bonds: The risk and returns" The Journal of Structured Finance (15:4), pp. $75-83$.

Tongzon, J. and Heng, W. (2005), "Port privatization, efficiency and competitiveness: Some empirical evidence from container ports (terminals)", Transportation Research, Part A, 39, pp. $405-424$.

Wiegmans, B., Ubbels, B., Rietveld, P. and Nijkamp, P. (2002), "Investment in Container Terminals: Public Private Partnerships in Europe", International Journal of Maritime Economics 2002, p. 4. 